\title{
PROFIL PLASMA NUTFAH DAN JENIS PENYAKIT PISANG LOKAL ASAL PANDEGLANG BANTEN
}

\author{
NANI MARYANI \\ SUSILAWATI DEWI \\ RIDA OKTORIDA KHASTINI \\ INDAH JUWITA SARI
}

Jurusan Pendidikan Biologi, FKIP, Universitas Sultan Ageng Tirtayasa

Jl. Raya Jakarta Km 4. Pakupatan Serang Banten

Email: nani.maryani@untirta.ac.id

\begin{abstract}
Banana is one of the most favorite fruit in the world. Indonesia is at the center of the origin and the diversity of banana in Southeast Asia. One of the highest volume of banana producers in Indonesia is the Province of Banten. However, no information about the diversity of banana and its related diseases that may have found within the bananas from this province. This paper aims to explore the diversity of local banana and its related diseases in Banten's Pandeglang Regency. The research method used was to survey, to collect, and to identify local banana varieties and diseases associated with these varieties in Desa Cadasari. Eleven local bananas were identified as related to Fusarium wilt, Sigatoka, and Blood. Seven local banana germplasm is described in this paper. This research is very important for preserving Indonesia's biodiversity and will be useful for food security and sustainability in the future.
\end{abstract}

Key words: Banana, Banten, diversity, diseases, Pandeglang

\begin{abstract}
Abstrak. Pisang adalah buah paling favorit di dunia. Indonesia berada di titik pusat asal dan keanekaragaman pisang di Asia Tenggara. Banten adalah salah satu penghasil pisang paling banyak di Indonesia. Namun, tidak ada informasi tentang keragaman pisang dan penyakit terkait yang tersedia dari provinsi ini. Makalah ini bertujuan untuk mengeksplorasi keanekaragaman pisang lokal dan penyakit terkait di Kabupaten Pandeglang Banten. Metode penelitian yang digunakan adalah mensurvei, mengumpulkan, dan mengidentifikasi varietas pisang lokal dan penyakit yang terkait dengan varietas tersebut di Desa Cadasari. Sebelas pisang lokal diidentifikasi terkait dengan layu Fusarium, Sigatoka, dan Darah. Tujuh plasma nutfah pisang lokal dijelaskan dalam makalah ini. Hasil penelitian yang dilakukan berupa informasi ini sangat penting untuk melestarikan keanekaragaman hayati Indonesia dan akan berguna untuk ketahanan pangan dan keberlanjutan di masa depan.
\end{abstract}

Kata Kunci: Pisang, Banten, keanekaragaman, penyakit, Pandeglang

\section{PENDAHULUAN}

Pisang merupakan (Musa spp.) merupakan buah populer dan sangat disukai diberbagai belahan dunia. Bahkan di banyak negara Afika dan Amerika Latin, Pisang merupakan pangan utama (makanan pokok). Setiap tahunnya konsumsi Pisang dunia mencapai lebih dari 100 juta ton, menjadikannya sebagai tanaman dengan produksi paling tinggi setelah gandum, beras, dan jagung (FruitTrop magazine 2017, www.fao.org). Indonesia merupakan salah satu negara penghasil Pisang terbesar di dunia yang menduduki peringkat 6 setelah India, Cina, Filipina, Ekuador, dan Brazil (www.fao.org/2016). Dalam skala nasional, Pisang merupakan buah unggulan yang menduduki peringkat satu dalam hal produksi dan konsumsi, serta luasan panen wilayah pertanamannya (www.bps.go.id, Pusdatin 2016). Produksi Pisang di Indonesia 
umumnya dihasilkan dari pekarangan rumah (backyard plantation), hanya sedikit yang dihasilkan dari perkebunan komersial yang luas. Hampir seluruh produksi Pisang nasional digunakan untuk konsumsi lokal (90\%) dan hanya sebagian kecil untuk ekspor (10\%).

Indonesia merupakan salah satu kawasan pusat asal-usul (centre of origin) dan keragaman (centre of diversity) Pisang dunia. Wilayah kepulauan Indonesia merupakan tempat tumbuh dua spesies Pisang liar berbiji (wild Musa) Musa acuminata Colla (AA) dan Musa balbisiana Colla (BB) yang merupakan nenek moyang Pisang budidaya (cultivated varieties $=$ Kultivar) (Simmonds 1962). Dari 71 spesies Pisang liar yang ada di dunia, 15 diantaranya yang merupakan sub-spesies Musa acuminata berasal dan tumbuh di Indonesia (Ahmad 2013, Nasution 1990, Simmonds 1962). Lebih dari 200 jenis kultivar Pisang lokal di Indonesia telah diidentifikasi dan dipreservasi dengan baik. Jumlah ini diperkirakan akan meningkat menjadi 500 kultivar dari seluruh wilayah Indonesia mulai dari Aceh hingga Papua (Maryani 2018). Plasma nutfah (germplasm) Pisang liar dan Pisang budidaya ini sangat penting karena merupakan sumber daya genetik yang dapat digunakan untuk tujuan preservasi dan program pemuliaan tanaman Pisang (Breeding) untuk menghasilkan varietas unggul dan tahan penyakit.

Provinsi Banten merupakan salah satu sentra produksi Pisang di Indonesia. Berdasarkan data rata-rata produksi Pisang selama tahun 2011-2015, terdapat 11 (sebelas) provinsi sentra produksi Pisang yang memberikan kontribusi hingga 88,07\% produksi nasional. Provinsi Banten berada di urutan ke-6 setelah Provinsi Jawa Timur, Jawa Barat, Lampung, Jawa Tengah, dan Sumatera Utara (www.bps.go.id, Pusdatin 2016, Gambar 1). Pada akhir tahun 2016, total produksi Pisang di Banten mencapai 162.853 ton/ tahun dengan luas panenan 2,618 hektar/ tahun, dengan Kabupaten Pandeglang merupakan daerah penghasil Pisang terbesarnya (www.bps.go.id, Pusdatin 2016). Jumlah produksi dan luasan panen ini merupakan aset wilayah yang dapat dijadikan potensi unggulan sosial ekonomi.

Studi tentang keragaman plasma nutfah Pisang di Indonesia, khususnya di Banten belum banyak dilaporkan dan diketahui. Padahal plasma nutfah yang merupakan sumber daya kearifan lokal yang unik dan khas disetiap wilayah. Pada tahun 2014-2015, peneliti melakukan perjalanan di Pulau Jawa termasuk wilayah barat dan beberapa wilayah di Provinsi Banten. Begitu pula mengenai jenis penyakit yang menyerang tanaman tersebut.

Tujuan dari penelitan ini adalah untuk menginventarisasi keragaman plasma nutfah Pisang dan jenis penyakit yang menyerangnya di Kabupaten Pandeglang. Informasi ini merupakan penelitian dasar yang dapat dikembangakan menjadi penelitian terapan di berbagai disiplin ilmu dengan objek utama buah Pisang dan mikroba patogennya. Koleksi banana germplasm asal Banten merupakan bagian penting terciptanya food sustainability and food security dikawasan ini. Meskipun Pisang bukanlah pangan utama di Indonesia, namun peranan komoditas hortikultur ini sangat penting yang dapat dikembangkan sebagai buah lokal unggulan maupun pangan olahan lokal dengan potensi ekonomi yang sangat besar.

\section{METODE}

\section{Lokasi sampling}

Lokasi eksplorasi dipilih berdasarkan random sampling dari 57 kecamatan yang ada di Kabupaten Pandeglang. Kecamatan Cadasari terpilih sebagai lokasi sampling. Kecamatan Cadasari terletak di $6^{\circ} 15^{\prime} 19.1^{\prime \prime S} 106^{\circ} 05^{\prime} 53.6^{\prime \prime}$ E adalah salah satu kecamatan di Pandeglang yang merupakan sentra penanaman pisang (Gambar 1). 


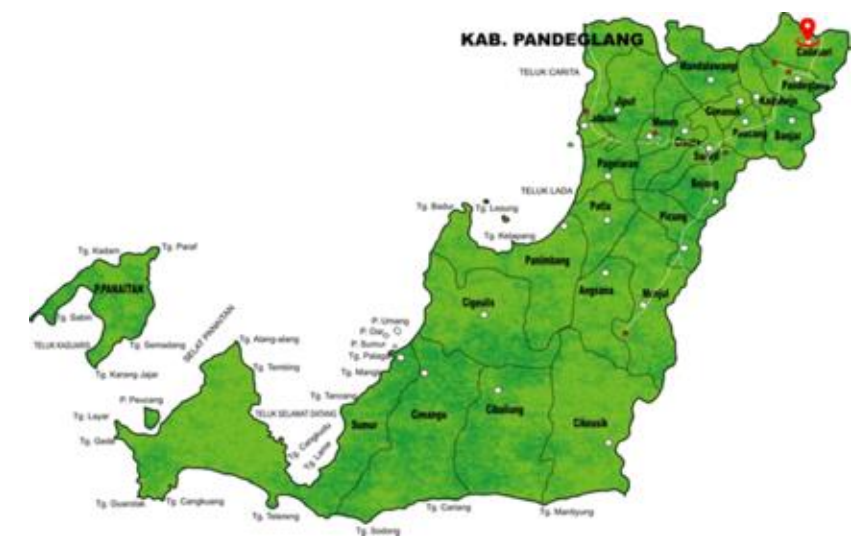

Gambar 1. Peta Kabupaten Pandeglang, Banten. Tanda merah menunjukkan lokasi pengambilan sampel Kecamatan Cadasari.

(www.pa-pandeglang.go.id)

Koleksi hidup plasma nutfah pisang lokal

Nama lokal kultivar Pisang, data GPS lokasi, kondisi ekologi seperti pH tanah, intensitas cahaya, dan jenis tanaman sekitar pohon dicatat dan didokumentasikan dengan kamera resolusi baik. Koleksi hidup plasma nutfah Pisang diperoleh dengan mengambil bagian bonggol anakan pisang (corm) yang bebas patogen. Bonggol pisang dibersihkan kemudian dibawa untuk ditanam sebagai koleksi hidup di kebun pribadi peneliti di Kecamatan Banjar Agung Kota Serang.

\section{Identifikasi plasma nutfah pisang}

Identifikasi plasma nutfah pisang lokal menggunakan kunci identifikasi morfologi pisang dengan skoring mengacu pada Simmond \& Shepherd (1955), Valmayor et al. (1999) dan Poerba et al. (2018) (Tabel 1.). Kunci identifikasi ini mencakup semua jenis plasma nutfah pisang dalam kelompok genom AA, AB, AAA, AAB, ABB, dan AAB. Data koleksi Pisang yang diperoleh dicatat dan dibukukan menjadi data paspor. Data ini meliputi foto berwarna resolusi tinggi yang meliputi 15 karakter utama seperti bagian pohon dan buah, penampang melintang daun, bentuk daun, warna pseudostem, tandan buah, warna braktea bunga jantan, dan bentuk jantung. In-situ comparison dilakukan dengan membandingkan koleksi yang ditemukan dengan koleksi hidup Musa yang ada Pusat Penelitian Biologi LIPI Cibinong

Tabel 1. Pengelompokan pisang kultivar berdasarkan skor total

\begin{tabular}{cc}
\hline Kelompok Genom & Total Skor \\
\hline AA/AAA & $15-25$ \\
AAB & $26-46$ \\
AB/AABB & $47-49$ \\
ABB & $59-63$ \\
ABBB & $67-69$ \\
BB/BBB & $70-75$ \\
\hline
\end{tabular}

\section{Identifikasi penyakit}

Data penyakit yang menyerang kultivar Pisang lokal dilakukan dengan melihat gejala eksternal yang nampak pada Pisang dan membandingkannya dengan literatur mengacu pada Wiyono (2010). Sampel penyakit daun dikoleksi dengan cara menyimpan bagian daun yang menampakkan gejala dalam kertas amplop lalu dipak dalam box berisi silica gel. Sampel penyakit berupa gejala dalam pseudostem dan bonggol dikoleksi dengan memotong bagian xylem dan membungkusnya dengan kertas serap lalu dipak dalam amplop dan dimasukkan 
dalam box dengan silica gel (Gambar 2.). Sampel-sampel ini kemudian dibawa ke laboratorium Pendidikan Biologi UNTIRTA untuk dianalisis lebih lanjut.

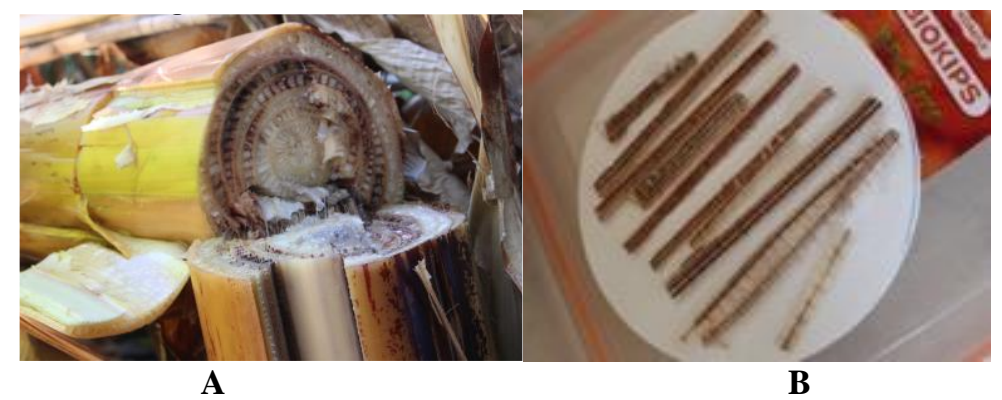

Gambar 2. Metode koleksi sampel penyakit dengan gejala pada pseudostem pisang A. Gejala internal diskolorasi pada pseudostem pisang yang terserang penyakit. B. pseudostem dipotong dan dipak dalam filter paper.

\section{HASIL DAN PEMBAHASAN}

Diversitas Plasma Nutfah Pisang Lokal Cadasari dan penyakitnya

Sebelas aksesi Pisang lokal diketahui dan diidentifikasi di Kecamatan Cadasari Kabupaten Pandeglang Banten. Pisang-pisang lokal ini sangat rentan terhadap beberapa penyakit yang umum menyerang Pisang (Tabel 2). Dua jenis Pisang lokal yang ditemukan tidak menunjukkan gejala penyakit yaitu Pisang Raja Sereh dan Pisang Muli.

Penyakit yang paling banyak menyerang Pisang lokal Cadasari adalah penyakit layu Fusarium atau Fusarium wilt (Gambar 3A). Tanaman Pisang yang terserang Fusarium wilt menunjukkan gejala daun menjadi layu dan kuning, internal pseuodstem dan bonggol (corm) berwarna kecokelatan (discoloration), pohon menjadi tidak produktif. Fusarium wilt disebabkan oleh sekelompok patogen tular tanah (soil-borne fungi) dari genus Fusarium. Telah diketahui bahwa selain merupakan pusat asal usul Pisang Indonesia juga merupakan pusat diversitas patogen Fusarium wilt (Maryani et al. 2019). Patogen ini telah tersebar di pulau-pulau di Indonesia dan penelitian ini menunjukkan kepada kita bahwa Fusarium wilt juga terdeteksi di Banten. Sampai saat ini belum ada teknologi eradikasi yang efektif untuk memberantas penyakit Fusarium wilt karena struktur dorman Fusarium yang dapat bertahan dalam tanah hingga 30 tahun.

Tabel 2. Profil 11 plasma nutfah Pisang lokal Cadasari meliputi nama lokal, kerentanan terhadap penyakit dan lokasi

\begin{tabular}{clll}
\hline No. & \multicolumn{1}{c}{ Nama Lokal } & \multicolumn{1}{c}{ Penyakit } & \multicolumn{1}{c}{ Lokasi } \\
\hline 1 & Pisang Ketan & Sigatoka & Kampung. Pasir, Desa \\
2 & Pisang Nangka & Sigatoka & Cadasari \\
3 & Pisang Ambon & Sigatoka & Kp. Pasir, Desa Cadasari \\
4 & Pisang Ketan & Fusarium Wilt, Sigatoka, Blood & Kp. Waas, Desa Cadasari \\
5 & Pisang Kepok & Disease & Kp. Waas, Desa Cadasari \\
6 & Pisang Raja Pandan & Fusarium Wilt, Sigatoka & Kp. Waas, Desa Cadasari \\
7 & Pisang Nangka & Fusarium Wilt & Kp. Waas, Desa Cadasari \\
8 & Pisang Raja Sereh & Resisten & Kp. Waas, Desa Cadasari \\
9 & Pisang Tanduk & Fusarium Wilt & Desa Cigadung \\
10 & Pisang Muli & Resisten & Desa Cigadung \\
11 & Pisang Tanduk & Fusarium Wilt & Desa Cigadung \\
\hline & & & Desa Cigadung \\
\hline
\end{tabular}


Sigatoka merupakan penyakit lain yang ditemukan menyerang kultivar lokal di Cadasari Pandeglang (Gambar 3B). Sigatoka (black leaf streak disease) merupakan penyakit tular udara yang menyerang daun pisang yang disebabkan oleh fungi Pseudocercospora fijiensis. Gejala yang ditimbulkan diantaranya bercak kuning-kecokelatan pada daun pisang yang akhirnya melebar dan menyebabkan masif necrosis pada daun (Marin et al. 2003). Penyakit ini merupakan penyakit penting yang menyerang Pisang dan metode pengendalian umum yang digunakan adalah menggunakan pestisida (Ploetz 2000). Penyakit darah atau blood disease yang umum menyerang varietas Pisang Kepok juga ditemukan di Kecamatan Cadasari. Namun varietas Pisang lokal yang terserang blood disease adalah jenis pisang lokal varietas Pisang Ketan. Blood disease disebabkan oleh bakteri Ralstonia sp. yang menyebabkan buah menjadi keras dan cokelat sehingga tidak dapat dikonsumsi lagi (Gambar 3C). Persebaran penyakit ini umumnya ditularkan oleh binatang seperti Kalong atau serangga lain.

Penyakit tanaman mempunyai dampak yang sangat besar yang dapat merubah tananan ekonomi sosial suatu bangsa (Bebber et al. 2014). Pentingnya mengetahui penyakit yang menyerang buah utama di Indonesia, pisang, tidak dapat dipungkiri. Hasil penelitian ini membuka mata kita bahwa pisang-pisang lokal di Banten telah terserang minimal tiga penyakit utama pisang. Kesadaran masyarakat mengetahui jenis-jenis penyakit yang menyerang pisang akan memudahkan metode penanggulangan penyakit yang tepat.
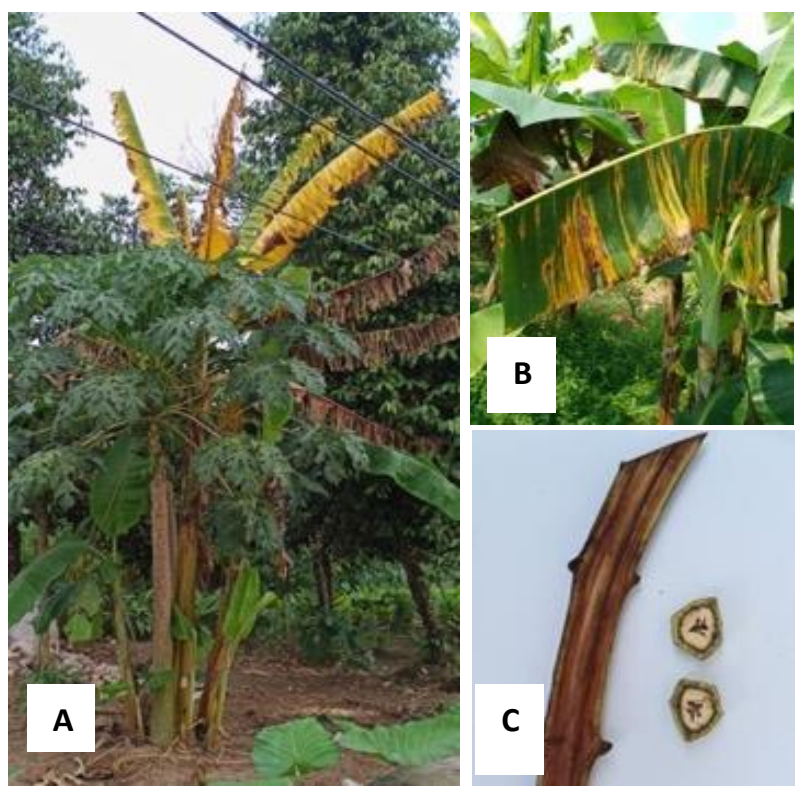

Gambar 3. Penyakit yang menyerang Pisang lokal di Pandegalang. A. Layu Fusarium, B. Sigatoka, C. Penyakit darah (Blood disease).

\section{Identifikasi Morfologi Plasma Nutfah Pisang Lokal Cadasari}

Tujuh aksesi pisang lokal yang ditemukan di Kecamatan Cadasari berhasil dideskripiskan dan diidentifikasi dengan baik menggunakan kunci identifikasi morfologi. Meskipun tidak semua aksesi Pisang yang diidentifikasi dalam penelitian ini memiliki 15 karakter lengkap namun komparasi dengan koleksi hidup membantu peneliti menemukan kekosongan data sehingga Pisang-pisang lokal ini dapat teridentifikasi secara akurat. Tabel karakteristik morfologi Pisang berdasarkan kunci identifikasi disajikan pada tabel 4. Aksesi-aksesi Pisang ini ditanam di kebun pribadi peneliti untuk selanjutnya dapat menjadi referensi koleksi hidup plasma nutfah Pisang lokal asal Cadasari Pandeglang. Data paspor karakteristik plasma nutfah Pisang lokal asal Cadasari disajikan pada gambar 4-10. 
Pisang lokal yang ditemukan dan didentifikasi di Cadasari Kabupaten Pandeglang yaitu, pisang Ketan, pisang Nangka, pisang Ambon, pisang Kepok, pisang Raja Sereh dan pisang Muli. Kultivar pisang jenis ini juga ditemukan di wilayah lain pulau Jawa, Sumatra dan Kalimantan (Muliawati et al. 2018, Maryani et al. 2018. Ismail et al. 2014). Jumlah skor digunakan untuk menentukan jenis genom pada tujuh kultivar pisang yang ditemukan di Pandeglang (Tabel 4.). Karakteristik morfologi pada batang semu adalah keberadaan warna bercak pada batang semu, beberapa varietas kultivar pisang memiliki batang semu tanpa bercak hitam sampai coklat (pisang Ketan, pisang Kepok, pisang Raja sereh dan pisang tanduk), varietas lainnya memiliki batang semu dengan bercak hitam sampai coklat yang sangat banyak (pisang Muli) dan bercak hitam sampai coklat yang tidak terlalu banyak (pisang Nangka dan pisang Ambon). Keberadaan bercak yang banyak dan melebar pada batang semu menunjukkan memiliki kecenderungan sifat Musa acuminata (Genom A) dan batang semu tanpa bercak coklat sampai hitam atau sangat sedikit bercak menunjukkan memiliki kecenderungan sifat Musa balbisiana (Genom B) (Poerba et al. 2018, Ahmad et al. 2013, Simmond \& Sepherd, 1955). Karakteristik morfologi pada daun adalah bentuk tepi saluran tangkai daun, keadaan bentuk tepi saluran daun berbeda pada beberapa verietas. Tepi saluran tangkai daun tegak dan membuka, bersayap dan tidak saling bertemu (mengatup) dimiliki oleh semua kultivar pisang yang ditemukan, kecuali pada pisang Kepok dan pisang Tanduk yang memiliki tepi saluran tangkai daun yang menutup tidak bersayap dan saling bertemu (mengatup). Tepi tangkai saluran daun yang terbuka bersayap dan tidak saling bertemu menunjukkan memiliki kecenderungan sifat Musa acuminata (Genom A) dan tepi tangkai saluran daun yang menutu[, tidak bersayap dan saling bertemu menunjukkan memiliki kecenderungan sifat Musa balbisiana (Poerba et al. 2018, Ahmad et al. 2013, Simmond \& Sepherd, 1955).

Tabel 4. Skor identifikasi morfologi tujuh plasma nutfah Pisang lokal asal Kecamatan

$$
\text { Cadasari }
$$

\begin{tabular}{|c|c|c|c|c|c|c|c|c|c|c|c|c|c|c|c|c|}
\hline \multirow{2}{*}{ Jenis Pisang } & \multicolumn{15}{|c|}{ Karakter } & \multirow{2}{*}{ Genom } \\
\hline & $\mathrm{A}$ & B & $\mathrm{C}$ & $\mathrm{D}$ & $\mathrm{E}$ & $\mathrm{F}$ & G & $\mathrm{H}$ & I & $\mathrm{J}$ & $\mathrm{K}$ & $\mathrm{L}$ & $\mathrm{M}$ & $\mathrm{N}$ & $\mathrm{O}$ & \\
\hline P. Ketan C1P & 5 & 1 & 2 & $\mathrm{~T}$ & $\mathrm{~T}$ & 2 & 2 & 1 & 1 & 2 & 3 & 1 & 5 & 1 & 4 & $\mathrm{AAB}$ \\
\hline P.Nangka C1P & 2 & 1 & 1 & 5 & $\mathrm{~T}$ & 2 & 2 & 3 & 3 & 2 & 2 & 1 & $\mathrm{~T}$ & 1 & 4 & $\mathrm{AAB}$ \\
\hline P.Ambon C2P & 3 & 1 & $\mathrm{~T}$ & $\mathrm{~T}$ & $\mathrm{~T}$ & 2 & $\mathrm{~T}$ & 2 & 3 & 2 & 3 & 1 & $\mathrm{~T}$ & 1 & 4 & AAA \\
\hline P.Kepok C2P & 5 & 4 & $\mathrm{~T}$ & $\mathrm{~T}$ & $\mathrm{~T}$ & $\mathrm{~T}$ & $\mathrm{~T}$ & $\mathrm{~T}$ & $\mathrm{~T}$ & $\mathrm{~T}$ & $\mathrm{~T}$ & $\mathrm{~T}$ & $\mathrm{~T}$ & $\mathrm{~T}$ & $\mathrm{~T}$ & $\mathrm{ABB}$ \\
\hline $\begin{array}{l}\text { P.Raja Sereh } \\
\text { C3P }\end{array}$ & 5 & 2 & $\mathrm{~T}$ & $\mathrm{~T}$ & $\mathrm{~T}$ & $\mathrm{~T}$ & 4 & $\mathrm{~T}$ & $\mathrm{~T}$ & $\mathrm{~T}$ & $\mathrm{~T}$ & $\mathrm{~T}$ & $\mathrm{~T}$ & $\mathrm{~T}$ & $\mathrm{~T}$ & $\mathrm{AAB}$ \\
\hline $\begin{array}{l}\text { P. Tanduk } \\
\text { C3P }\end{array}$ & 5 & 5 & $\mathrm{~T}$ & $\mathrm{~T}$ & $\mathrm{~T}$ & $\mathrm{~T}$ & $\mathrm{~T}$ & $\mathrm{~T}$ & $\mathrm{~T}$ & $\mathrm{~T}$ & $\mathrm{~T}$ & $\mathrm{~T}$ & $\mathrm{~T}$ & $\mathrm{~T}$ & $\mathrm{~T}$ & $\mathrm{AAB}$ \\
\hline P. Muli C3P & 1 & 1 & 5 & $\mathrm{~T}$ & $\mathrm{~T}$ & $\mathrm{~T}$ & 3 & $\mathrm{~T}$ & $\mathrm{~T}$ & $\mathrm{~T}$ & $\mathrm{~T}$ & $\mathrm{~T}$ & $\mathrm{~T}$ & $\mathrm{~T}$ & $\mathrm{~T}$ & AA \\
\hline
\end{tabular}

\section{Keterangan:}

A : Warna batang semu

B : bentuk tepi saluran tangkai daun

C : tangkai tandan

D : tangkai buah

E : susunan lembaga buah

$\mathrm{F}$ : bahu braktea

$\mathrm{G}$ : gulungan braktea 


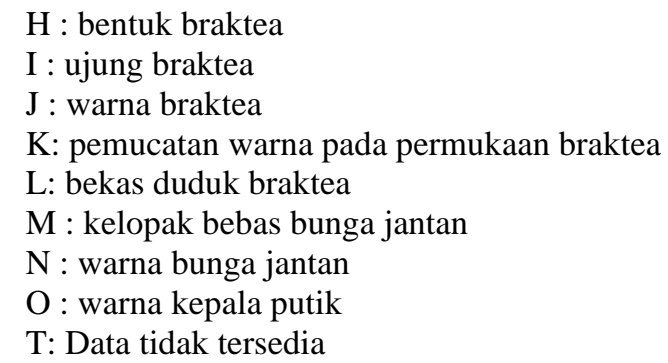

Data kekayaan plasma nutfah tanaman merupakan bagian penting usaha melestarikan biodiversitas nasional terutama pada tanaman-tanaman penting bagi ekonomi. Tersedianya sumber plasma nutfah yang melimpah akan meningkatkan jaminan food security and food sustainability pada saat kritis pangan. Sejarah mengajarkan kepada kita bahwa serangan penyakit tanaman dapat menyebabkan kerugian ekonomi bahkan menyebabkan kelaparan. Diakhir tahun 60-an, industri pisang di latin Amerika menjadi bangkrut karena serangan Fusarium wilt pada varietas Gros Michel yang mereka tanam. Sampai akhirnya industri pisang kembali bangkit dengan ditemukannya varietas Cavendish (Ploetz 2015). Menjadi sebuah urgensi bagi Indonesia sebagai negara asal-usul dan pusat diversitas pisang untuk mulai menginventarisasi dan mereservasi plasma nutfah yang masih belum banyak ditemukan. Penelitian ini memberikan kontribusi bagi usah tersebut khususnya Provoinsi Banten dimana belum ada data mengenai kekayaan pisang dan jenis penyakit-penyakit yang menyerangnya.

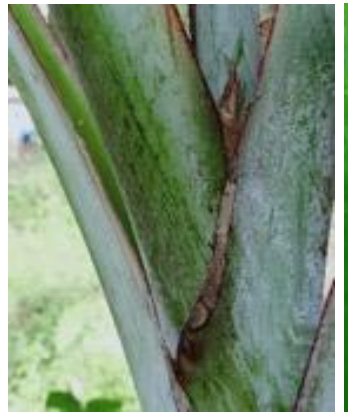

A

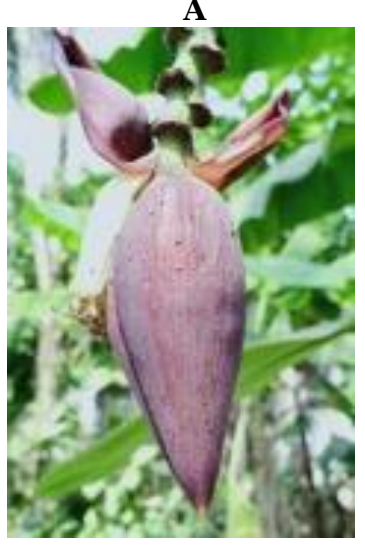

$\mathbf{F}$

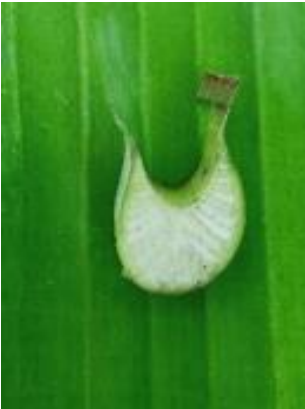

B

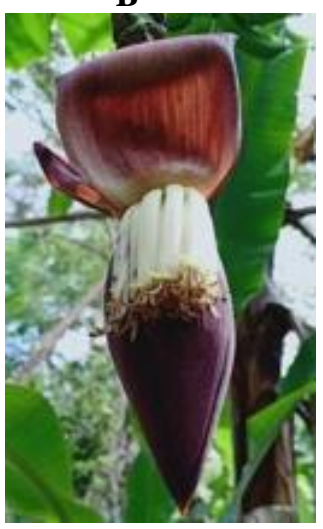

G

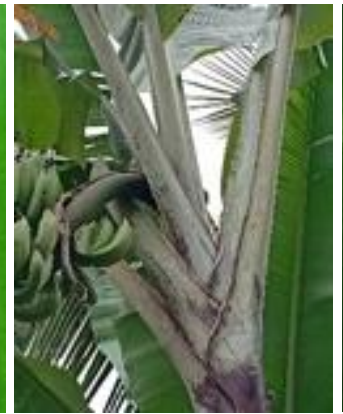

C

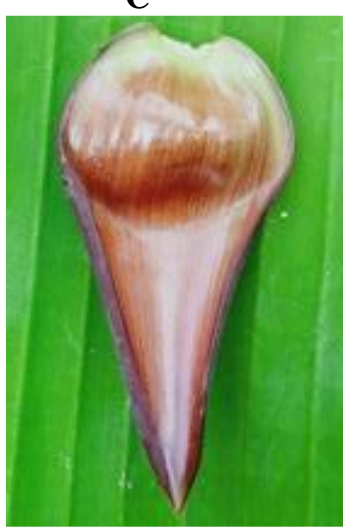

$\mathbf{H}$

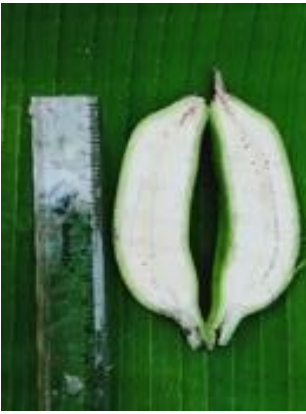

$\mathbf{E}$

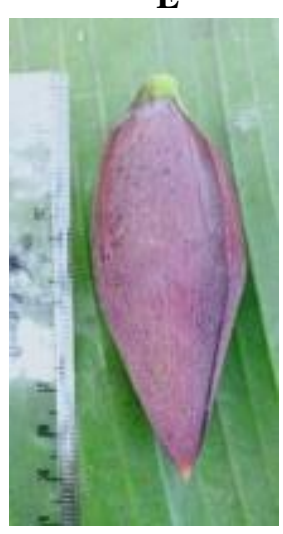


Faktor Exacta 12(4): 291-302, 2019

p-ISSN: 1979-276X

e- ISSN: 2502-339X

DOI : 10.30998/faktorexacta.v12i4.4912

Maryani N, dkk - Profil Plasma Nutfah Dan Jenis...

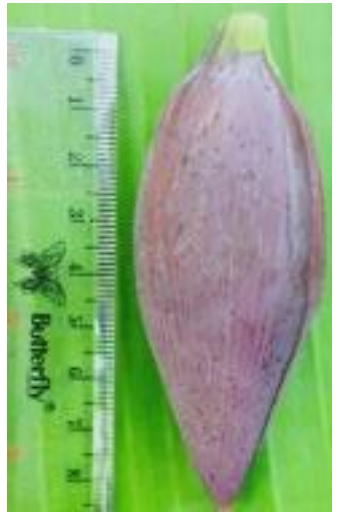

$\mathbf{J}$

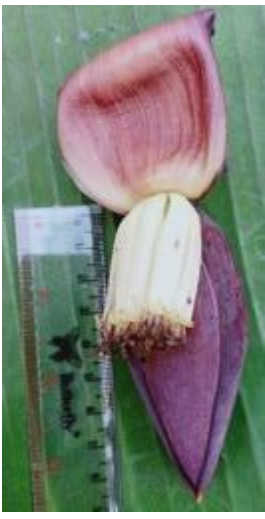

$\mathbf{K}$

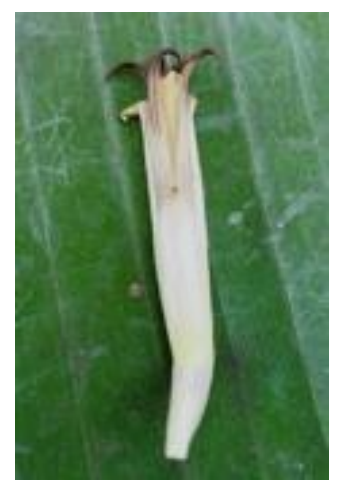

$\mathbf{N}$

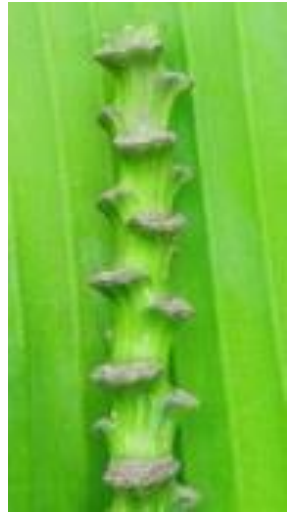

$\mathbf{L}$

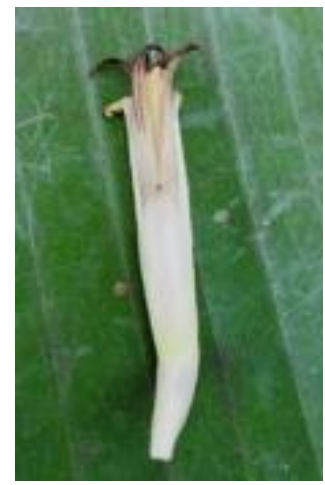

$\mathbf{O}$

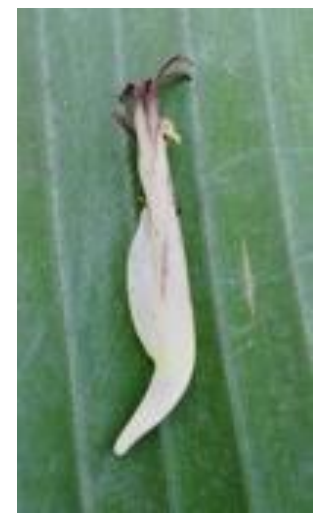

M

Gambar 4. Aksesi Pisang Ketan C1P (Keterangan gambar pada Table 4).

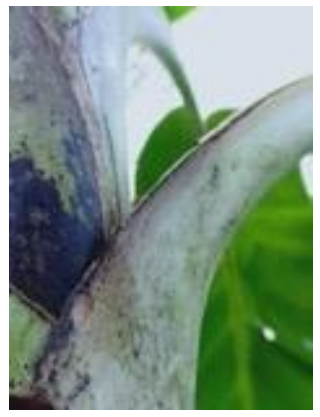

A

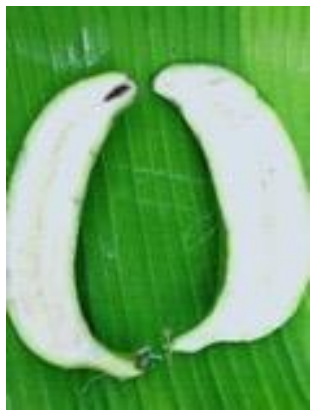

$\mathbf{E}$

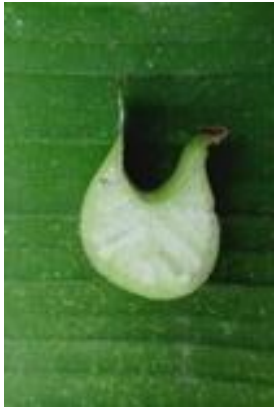

B

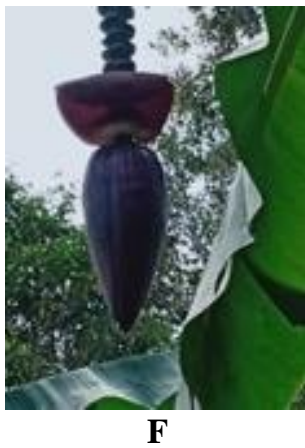

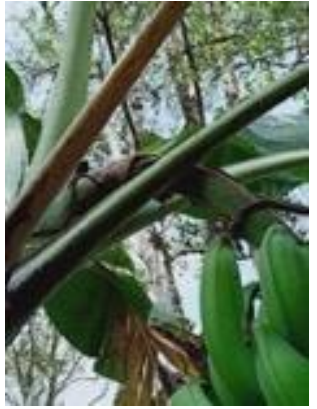

C

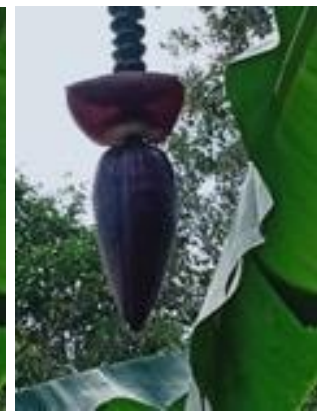

G

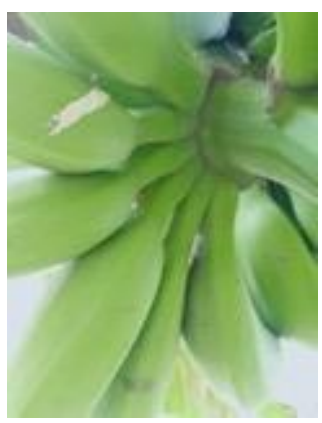

D

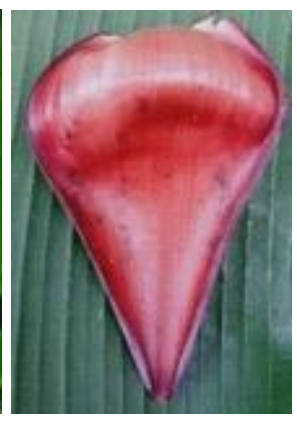

H 
Faktor Exacta 12(4): 291-302, 2019

p-ISSN: 1979-276X

e- ISSN: 2502-339X

DOI : 10.30998/faktorexacta.v12i4.4912

Maryani N, dkk - Profil Plasma Nutfah Dan Jenis...

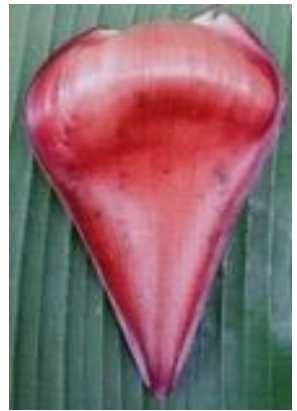

I

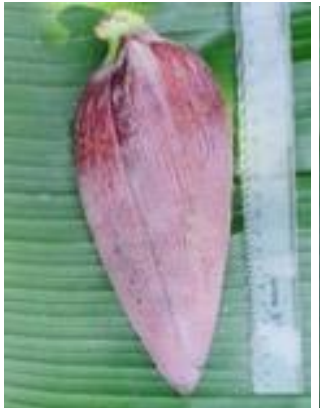

$\mathbf{J}$

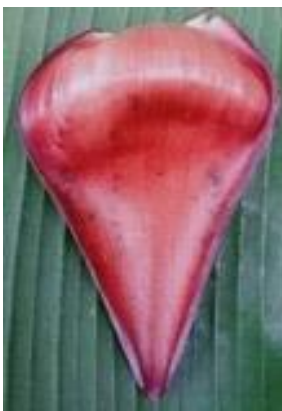

$\mathbf{K}$

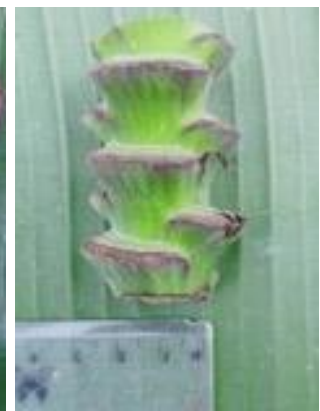

$\mathbf{L}$

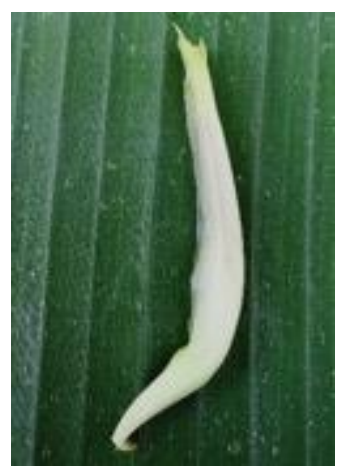

M

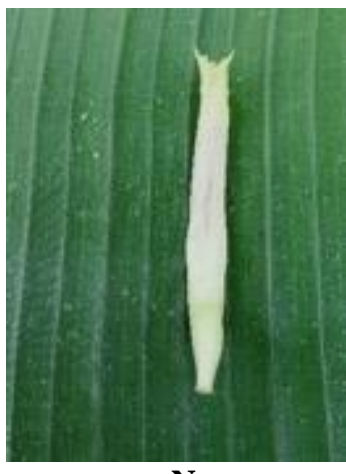

$\mathbf{N}$

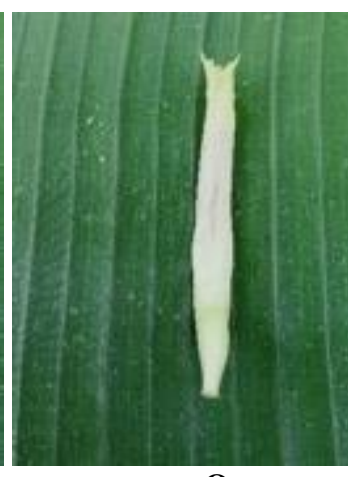

O

Gambar 5. Aksesi Pisang Nangka C1P (Keterangan gambar pada Table 4).

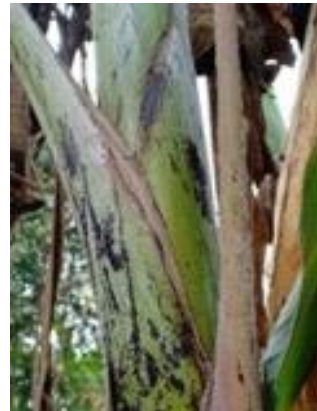

A

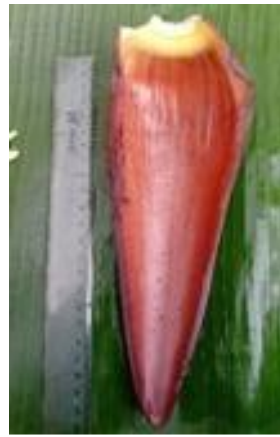

I

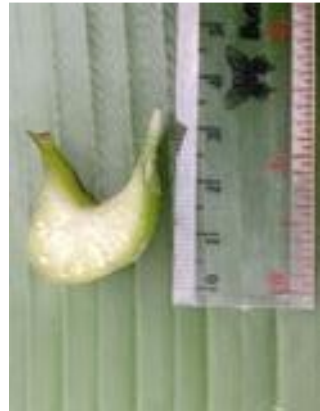

B

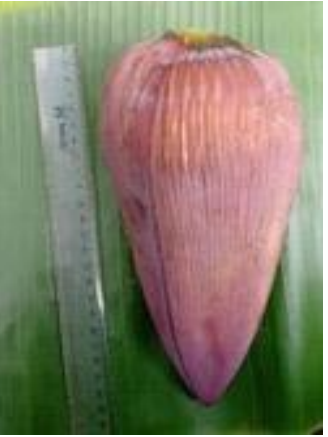

J

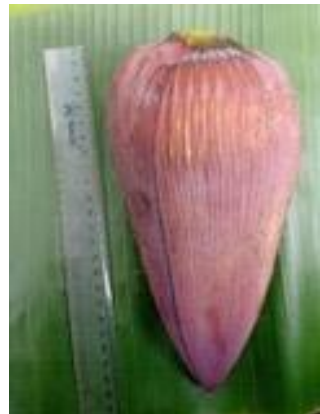

F

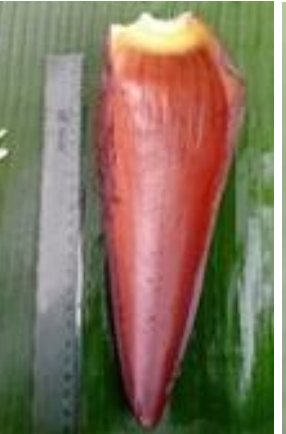

K

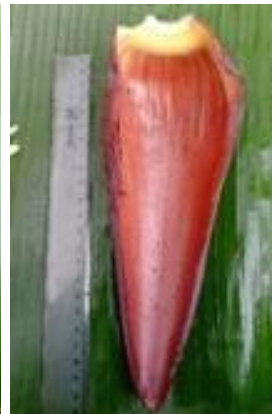

H 
Faktor Exacta 12(4): 291-302, 2019

p-ISSN: 1979-276X

e- ISSN: 2502-339X

DOI : 10.30998/faktorexacta.v12i4.4912

Maryani N, dkk - Profil Plasma Nutfah Dan Jenis...

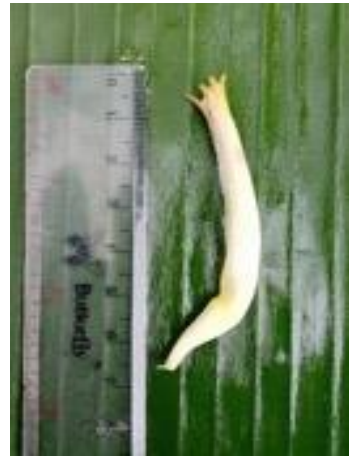

M

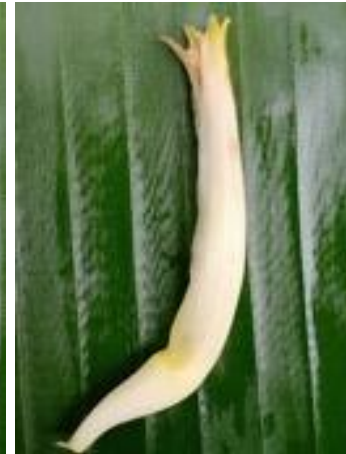

$\mathbf{N}$

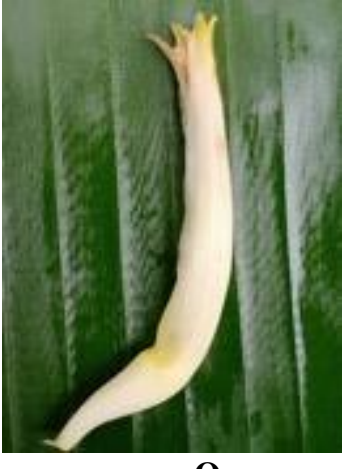

$\mathbf{O}$

Gambar 6. Aksesi Pisang Ambon C2P (Keterangan gambar pada Table 4).

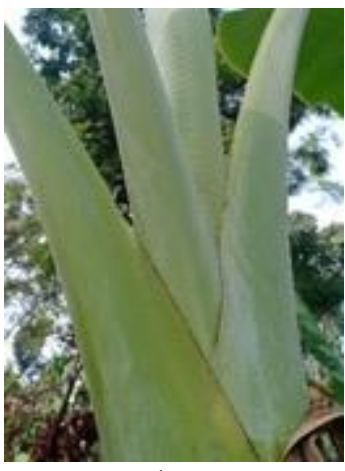

A

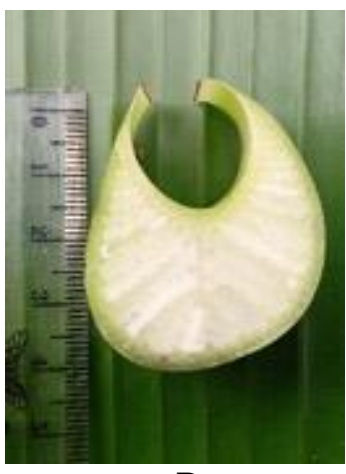

B

Gambar 7. Aksesi Pisang Kepok C2P (Keterangan gambar pada Table 4).

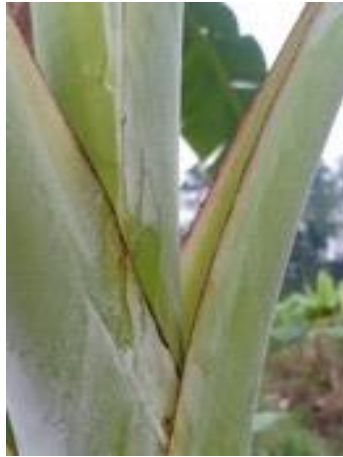

A

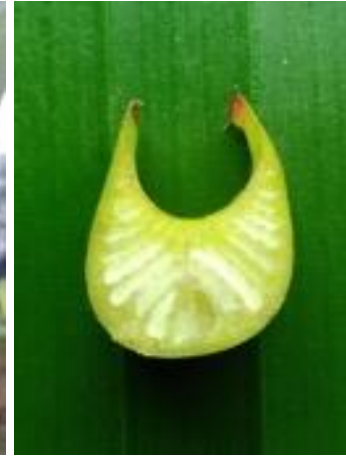

B

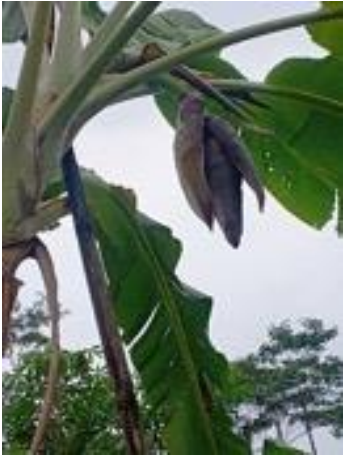

G

Gambar 8. Aksesi Pisang Sereh C3P (Keterangan gambar pada Table 4).

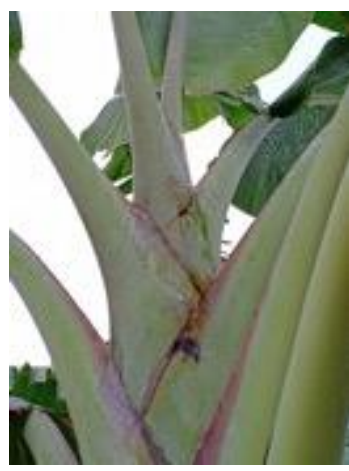

A

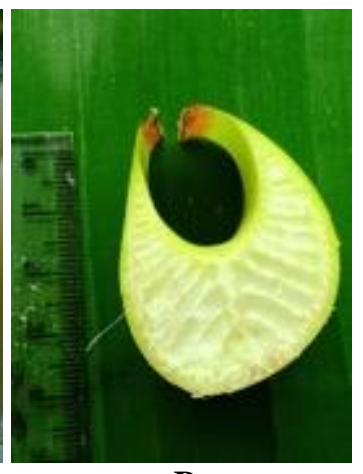

B 
Gambar 9. Aksesi Pisang Tanduk C3P (Keterangan gambar pada Table 4).

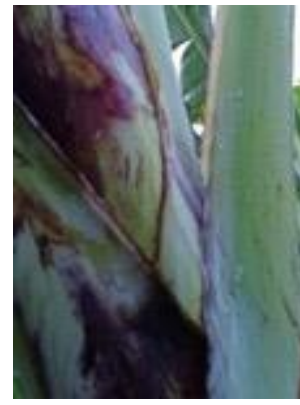

A

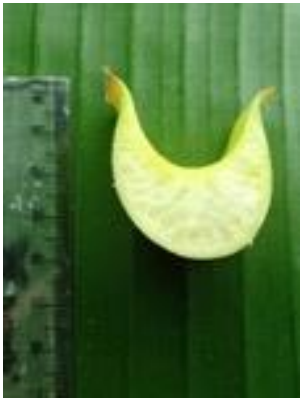

B

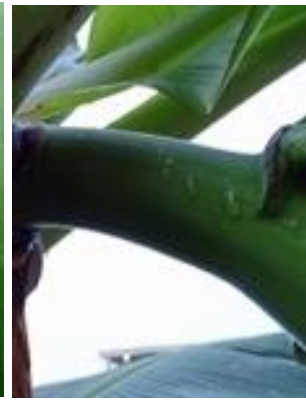

C

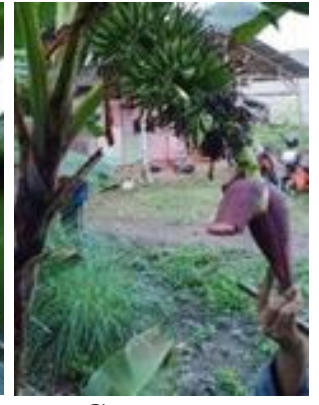

G

Gambar 10. Aksesi Pisang Muli C3P (Keterangan gambar pada Table 4).

\section{PENUTUP}

Simpulan

Eksplorasi dan identifikasi plasma nutfah Pisang lokal telah sukses dilakukan di Kecamatan Cadasari Kabupaten Pandeglang Provinsi Banten. Sebelas aksesi pisang lokal diketahui kerentanan dan ketahannya terhadap penyakit Fusarium wilt, sigatoka dan blood disease. Tujuh Plasma nutfah Pisang lokal diidentifikasi menggunakan ciri morfologi dan komparasi dengan koleksi hidup. Penelitian ini memberikan informasi awal keragaman Pisang lokal di Banten yang selanjutnya dapat dilanjutkan dan menjadi referensi sumber plasma nutfah Pisang lokal asal Banten untuk kegiatan pendidikan, penelitian dan preservasi biodiversitas Pisang.

\section{Saran}

Penelitian selanjutnya akan mendeskripsikan keragaman patogen fungi yang diisolasi dan didentifikasi dari plasma nutfah lokal pada penelitian ini. Fungi hasil isolasi selanjutnya dapat digunakan untuk uji patogenisitas baik terhadap varietas host maupun varietas yang tahan penyakit. Potensi sebagai agen hayati (biological control) juga dapat digunakan sebagai bahan kajian. Plasma nutfah Pisang yang tahan dapat dikaji lebih lanjut dan dapat digunakan sebagai varietas lokal unggul yang tahan terhadap penyakit-penyakit penting pada Pisang.

\section{UCAPAN TERIMA KASIH}

Penelitian ini merupakan bagian dari penelitian hibah PDUI UNTIRTA yang didanai oleh Islamic Development Bank (IsDB). Peneliti berterima kasih kepada Fajaruddin Ahmad (Laboratorium Genetika, Pusat Biologi LIPI Cibinong) yang telah membantu identifikasi jenis kultivar pisang, Siti Yuliyanti, Elmira R.O.H, S. Nursaffanah Hasna, Rahayu Juliyanti yang telah membantu koleksi dan analisis laboratorium penyakit Pisang pada penelitian ini.

\section{DAFTAR PUSTAKA}

Ahmad, F. 2013. Keragaman Genetik Pisang Musa balbisiana Colla di Indonesia menggunakan penanda Amplified Frangment Length Polymorphism (AFLP). Master thesis Sekolah Pasca Sarjana Institut Pertanian Bogor (IPB).

Bebber, D. P, Holmes, T dan Gurr, S. J. 2014. The global spread of crop pests and pathogens. Global Ecology and Biogeography - Volume 23.

FAOSTAT. 2016. http://www.fao.org/faostat/.

FruitTrop magazine. 2017. Banana and avocado close-ups. Banana statistqiues, April edition: 86-87. CIRAD Agricultural for development, Montpellier, France.

Ismail, A, Rachmadi, M dan Bana, N. 2014. Eksplorasi Jenis-Jenis Pisang Plantain Lokal Asal Desa Sukaharja Dan Desa Sukamulih Tasikmalaya Jawa Barat Sebagai Sumber Bibit Unggul. Jurnal Aplikasi Ipteks untuk Masyarakat - Volume 3, No. 2. 
Marín, D. H, Romero R. A, Guzmán, M dan Sutton, T.B. 2003. Black Sigatoka: An increasing threat to banana cultivation. Plant Disease - Volume 87, 208-222.

Maryani, N, Lombard, L, Poerba, Y. S, et al. 2019. Phylogeny and genetic diversity of the banana Fusarium wilt pathogen Fusarium oxysporum $f$. sp. cubense in the Indonesian centre of origin. Studies in Mycology - Volume 92.

Maryani, N. 2018. A complex relationship: Banana and Fusarium in Indonesia. Thesis dissertations, Experimental Plant Sciences Wageningen University The Netherlands.

Muliawati, E. S, Parjanto dan Hidayati, K. N. 2018. Peran Keanekaragaman Hayati untuk Mendukung Indonesia sebagai Lumbung Pangan Dunia. Seminar Nasional Dalam Rangka Dies Natalis UNS Ke 42 - Volume 2, No. 1.

Nasution, R. E. 1990. A Taxonomic Study of the Species Musa acuminata Colla with its intraspesific taxa in Indonesia. Ph.D dissertation Tokyo University of Agriculture, Japan.

PAP. 2017. www.pa-pandeglang.go.id/

Ploetz, R. 2000. Black Sigatoka. Pesticide Outlook - Volume 11, No.1.

Ploetz, R. C, Kema, G. H. J dan Ma, L. J. 2015. Impact of diseases on export and smallholder production of banana. Annual Review of Phytopathology - Volume 53.

Poerba, Y. S, Witjaksono, Martanti, D, et al. 2018. Katalog Pisang, Koleksi Kebun Plasma Nutfah Pisang Pusat Penelitian Biologi Lembaga Ilmu Pengetahuan Indonesia. Jakarta: LIPI Press.

PUSDATIN. 2016. http:// www.bps.go.id,

Simmonds, N \& Shepherd, K. 1955. The taxonomy and origins of the cultivated bananas. Journal of the Linnean Society of London Botany - Volume 55.

Simmonds, N. 1962. The Evolution of Bananas. London: Longman ltd.

Valmayor, R. V, Jamaluddin, S. H, Silayoi, J. S.B, et al. 1999. Banana cultivar names and synonyms in Southeast Asia. INIBAP Montpellier France.

Wiyono, S. 2010. Penyakit-penyakit penting tanaman pisang dan pengendaliannya. Departemen Prpteksi Tanaman. Fakultas Pertanian Institut Pertanian Bogor. 